\title{
George Woodcock and the Doukhobors: Peasant Radicalism, Anarchism, and the Canadian State
}

Intellectual History Review - in press

Matthew S. Adams, Loughborough University

\&

Luke Kelly, University of Manchester 


\title{
George Woodcock and the Doukhobors: Peasant Radicalism, Anarchism, and the Canadian State
}

\author{
Matthew S. Adams* \\ Department of Politics, History and International Relations, Loughborough University, UK \\ Luke Kelly ${ }^{\dagger}$ \\ Department of History, University of Manchester, UK
}

\begin{abstract}
For the British-Canadian writer and intellectual George Woodcock, the Doukhobors - a persecuted radical Christian sect, many members of which emigrated from Russia to Canada at the turn of the twentieth century - were a continual source of fascination. A cause célèbre for a host of nineteen-century thinkers, including Leo Tolstoy and Peter Kropotkin, the Doukhobors were frequently portrayed as the exemplars of the viewer's particular ideological beliefs. The present article examines Woodcock's shifting interpretation of the Doukhobors, mapped onto the development of an intellectual career that saw him emerge as a leading anarchist thinker, and his broader transition from a British writer to a Canadian public intellectual. Where once he saw the Doukhobors representing anarchism in action, as his politics matured his view of the sect became more complex. Rather than living anarchists, he came to see the Doukhobors' experience as a powerful reminder of the forces of assimilation at work in modern democracies that threatened the liberties of dissenters. Reflecting Woodcock's revised anarchist politics, the Doukhobors' story now became a key component of an intellectual vision that cast a probing light on Canadian history and Canadian cultural politics.
\end{abstract}

Keywords: anarchism, Doukhobors, Canada, public intellectuals, federalism, Trudeau

\footnotetext{
*Email: m.s.adams@lboro.ac.uk

+ Luke.kelly@manchester.ac.uk
} 
The British-Canadian historian, literary critic and public intellectual George Woodcock came to the story of the Doukhobors in part through his role as the most influential chronicler of anarchism's past. Publishing the first major biography of Peter Kropotkin, his key intellectual influence, in 1949, Woodcock was drawn to Kropotkin's role as a secular spokesperson for the group, noting that when he visited Canada in 1897, he was:

Enabled to repay the debt he owed to those Doukhobor peasant communists who ...influenced his ideas by their practical example. During the 1890 s the Doukhobors were subjected to violent attacks for their refusal to be conscripted. They stood firm... when it seemed clear that the Russian authorities intended to continue persecutions. ${ }^{1}$

Woodcock's fascination with the Doukhobors would prove enduring, and like so many thinkers before him, he strived to understand the group and their history through the lens of his politics. His intellectual journey, however, would impose revisions on this perception, just as the anarchism that he began to propagate in Britain in the 1930s developed into a more heterodox political creed in the 1950 s and ' 60 s. By this time, Woodcock had emerged as one of Canada's most important literary intellectuals. It may be simplistic to view him as 'Canada's "first man of letters", but this appellation was certainly central to his sense of self, seeing in the title a 'craftsmanly' commitment to advancing critical opinion in crystal prose. ${ }^{2}$ And this Woodcock achieved with striking productivity, writing, as one commentator observed, 'more than many literate people have read', on a host of subjects. ${ }^{3}$ In a poem dedicated to Woodcock, the poet Al Purdy looked to amend an older formulation to capture this variety: 
"Renaissance Man" has a grand sound

how about "binder twine"

not quite so culturally proud

but indicating useful pride. ${ }^{4}$

Politics was one 'twine' running through Woodcock's diverse achievements; political attachments that mutated as he moved between the old world and the new, as he embarked on fresh intellectual journeys, and as anarchism was reborn as a politics of protest in the 1960s. In this process, his understanding of the Doukhobors was subject to parallel transformations.

The plight of the Doukhobors had attracted the interest of anarchists long before Woodcock completed his influential study of the sect in 1968. As Woodcock's comments highlighted, Kropotkin argued that his exposure to the Doukhobors while undertaking military service in Siberia had revealed to him the power of cooperation:

To witness...the ways in which the communities of Dukhobors [sic]... migrated to the Amur region; to see the immense advantages which they got from their semi-communistic brotherly organization; and to realize what a success their colonialization was, amidst all the failures of State colonization, was learning something which cannot be learned from books. ${ }^{5}$

Kropotkin may have seen this direct experience as invaluable, but the late nineteenth century saw a great stream of ink spilt in examining this group of religious heretics. The Doukhobors - meaning 'spirit wrestlers', a name originally coined as a term of abuse denoting their apparent struggle against the Holy Ghost - soon became a cause célèbre in European radical 
circles, as their struggle against tsarist autocracy gained publicity through the efforts of sympathisers including Kropotkin and Leo Tolstoy. ${ }^{6}$

A key component of their appeal was the complex of radical principles that their struggle and example seemingly encapsulated. They rejected the authority of the Russian Orthodox Church and, indeed, the entire notion of priestly hierarchy. Many refused to cooperate with the Russian state or submit to military service, finding expression in a thoroughgoing pacifism, which even sometimes extended to vegetarianism. Reflecting their slogan, 'toil and peaceful life', the Doukhobors were dedicated to communal forms of social organisation and labour, as well as communistic distribution, and a subversion of conventional family structures shown in such habits as communal child-rearing. ${ }^{7}$ Given the breadth and pliability of these ideas, the Doukhobors soon became a vessel for a range of competing political enthusiasms, with European Christians, liberals, socialists and anarchists all highlighting particular practices as key, and identifying in the Doukhobor cause a mirror of their own political and religious ambitions.

The present article examines one example of the Doukhobors' appropriation by political radicals, focusing on Woodcock's shifting interpretation of the group mapped onto the development of his politics and intellectual life. The first section places Woodcock's analysis in a deeper context of Western political dissidence, exploring the ways in which nineteenth century thinkers representing a variety of traditions looked to the Doukhobors as exemplars of their particular political hopes. As the second section demonstrates, Woodcock, writing in Britain in the immediate wake of his turn to anarchism, inherited many of these essentially nineteenth century readings. For the early Woodcock, the Doukhobors represented a model of 
anarchism, attaining an elusive combination of communal solidarity, communism, and a rejection of political authority that offered empirical evidence of anarchism's possibility. The third section explores the ways in which Woodcock rethought this reading as he moved to Canada and met the Doukhobors. Mapped onto his developing intellectual identity as a Canadian writer with an interest in Canadian history and culture, and in the context of an invigorated political focus in the wake of Pierre Elliott Trudeau's election victory in 1968, the Doukhobors re-emerged in Woodcock's writing as a way of understanding and assessing the social and political changes at work. Rather than a positive model, the Doukhobors became a negative example of the effects of the centripetal force at work in modern democracies. Bearing the seeds of a philosophical self-reflection that led him to reshape his politics as a broader libertarianism, this politics similarly shaped Woodcock's work in Canadian cultural politics. The history and future of the Doukhobors remained, therefore, a common theme in Woodcock's work, and like his life and ideas in general, has not received sufficient attention. ${ }^{8}$ Examining his interpretation of the group in the context of his broader intellectual journey restores the importance of the political to his broad interests, while also highlighting the inappropriateness of seeing his reading of the Doukhobors as static. ${ }^{9}$ More valuably, however, it also allows us to comprehend the intellectual life of one of Canada's most important and distinctive critical voices; a figure, one commentator argues, matched only by Trudeau and George Grant as a distinctively Canadian twentieth-century thinker. ${ }^{10}$

\section{Under Western Eyes: The Radical Appeal of the Doukhobors}

Woodcock was introduced to the Doukhobors through the ideas of a number of nineteenthcentury thinkers. A divergently understood emblem of resistance to the state, example of 
communal living, and epitome of religious discipline, the Doukhobors were subject to varied scrutiny and support by radicals. From an ethnographic curiosity, to a cause célèbre among pacifists in the 1890 s, and then a challenge to integrationist officials in colonial Canada, the attention-grabbing sect sat at the crux of a number of ideological streams, and offered dissenters a vivid, real-life example of either a rural past or an ideal future, in the heart of modern Canada. Woodcock was among the Canadians who engaged most deeply with sect, particularly in his seminal study The Doukhobors. Shaping this reading, however, especially in his early work on the group, was their history of appropriation by political radicals of various stripes. This nineteenth century history therefore provided the architecture for his attempt to understand the wider significance of their particular struggles.

The Doukhobors were a small group of Russian peasants, one amongst a number of dissenting religious sects in nineteenth-century Russia distinguished by their refusal to worship in the Orthodox Church. None of their chroniclers pinpoint an exact origin, suggesting instead that they 'appeared', 'arose' or 'emerged into history' in the eighteenth century. ${ }^{11}$ The principal feature of the group was their rejection of all of the 'external rites and ceremonies' of Christianity. ${ }^{12}$ Instead they prayed 'inwardly at all times' and their gatherings were said to be filled with the spontaneous recitation of psalms and songs, passed down orally, with repeated bowing and kissing signalling a commitment to equality and brotherhood. ${ }^{13}$ Foreign observers tended to classify them in the language of Western ecclesiastical history as 'dissenters' of either a 'rational', 'mystical' or 'heretical' persuasion, ${ }^{14}$ with some opting to describe them as 'Russian Quakers' ${ }^{15}$ Observers were also often tempted to contrast their 'neat and clean dress, comfortable looking huts, and industrious habits, their numerous flocks, and extensive and well cultivated fields' with the 
apparently more slovenly habits of Orthodox Russians. ${ }^{16}$ As with many Russian peasants they held property in common, but went further in winning the admiration of liberals, socialists, and anarchists through a complex of beliefs and practices. The exact commitment to these principles tended to vary by Doukhobor community, but they often included, alongside communistic systems of sharing, an insistence on equality, including between genders, and even sometimes a strict vegetarianism. In the 1880s, Peter Vasilevich Verigin, who would lead the so-called Large Party of Doukhobors in the Caucasus, began a correspondence with Leo Tolstoy which would help solidify Doukhobor doctrine as pacifist, vegetarian and politically radical in the eyes of the world. ${ }^{17}$

The sect's tense relationship with the tsarist government in Russia was at the root of their positive appraisals by outsiders. ${ }^{18}$ In addition to dissenting from the Russian Orthodox Church in rejecting the mediation of priests, sacraments, or the Bible, Doukhobors often rejected another central pillar of the Russian state in asserting a profound pacifism. The tsarist government sought to punish or convert the sect, and in the 1790s dispersed certain groups of the Doukhobors to Finland and elsewhere, motivated by a desire to preserve Orthodox authority and enforce conscription. In 1802, they were encouraged to move to the fertile Molochnaya River area in modern-day Ukraine, a policy which both isolated their heresy and helped develop a sparsely populated area. With the ascension of Nicholas I in 1825, the Doukhobors position worsened. As an absolutist, Woodcock argued, Nicholas was convinced that the endurance of the Russian state depended on the institutions that the Doukhobors threatened - the Church and the army - and he opposed leniency 'towards pacifist sectarians' ${ }^{19}$ In the 1830 s, amidst allegations of sexual licentiousness and religiously motivated murder, the government exiled some Doukhobors to the Caucasus, again isolating 
them in an undeveloped region and forcing them to give up much of the wealth they had acquired in the previous colony. ${ }^{20}$

By the time of their coming to prominence in the 1890 s, the sect had been living on the borders of the Russian Empire for decades as part of the government's 'toleration through isolation' and colonization policies. ${ }^{21}$ The upholding of Doukhobor principles had always waxed and waned between generations and settlements, and many in the Caucasus had begun to carry weapons and accumulate wealth in the second half of the nineteenth century. In 1887, however, the government began to institute military service in the Caucasus, not excepting pacifists, as part of its project of modernisation. The Doukhobors' new leader, Peter Vasilevich Verigin, attempted to purify the Christian testimony of the sect, whose pacifism he thought had become lax under the influence of wealth, which produced a split in the group. In 1895, the more radical 'Large Party' of Doukhobors, led by Verigin, burned their weapons, prompting a government reaction that included flogging, imprisonment, and exile. ${ }^{22}$ Married to the attractiveness of their pacifism, the vegetarianism practised by some Doukhobors, and their championing by Tolstoy, such oppression by the agents of Russian autocracy prompted expressions of solidarity from Christians, anarchists and radicals in Russia, Europe, and North America. ${ }^{23}$

The widespread favour for the small peasant sect was based on a number of distinct ideas their example supposedly embodied, and while few engaged closely with the Doukhobors ideas and practices, many took their existence as a sign of stifled social and economic progress in Russia. The first point of interest was the Doukhobors' dissent from Russia's state church, which many took as an example of the democratic and modernising resources of 
Russian society that were usually stymied by autocracy. Sometimes this rested less on their concrete beliefs, or any conscious attempt to bring down the regime, than on their reputed example. The liberal Alexander Herzen's autobiography, for example, recounts a banished Doukhobor offer of help to a Decembrist exiled in Irkutsk. Herzen used this story to exhort would-be reformers to know 'the life of the people' and to offer an image of solidarity between classes:

And so in the forests and mines of Siberia, the Russia of Peter, of the landowner, of the public official, of the officer, and the 'black' Russia of the peasants and the village, both banished and fettered, both with an axe in the belt, both leaning on the spade and wiping the sweat from their faces, looked at each other for the first time and recognised the long-forgotten traits of kinship. ${ }^{24}$

He also recounted an anecdote of a Doukhobor whose refusal to bare his head for Tsar Paul I led to his imprisonment in a monastery. Here, however, the Doukhobor's honesty and teetotalism gained him a reputation for saintliness, even swaying his initially hostile Orthodox jailers. ${ }^{25}$ In neither story was Herzen concerned with the particular beliefs of the Doukhobors. Instead, he saw in their peculiar customs and principled resistance, signs of a Russia independent from the autocracy, while also distinct from the abstractions of educated political reformers. The Doukhobors were not a threat to the state, but their example of a genuine 'other Russia' demonstrated the possibility of democracy and modernisation far better than the theoretically driven schemes of reformist nobles. In this, the Doukhobors were presented in parallel ways to groups like the Mennonites, Molokans, and Stundists, with observers frequently noting, although seldom through detailed analysis, these groups' prosperity, cleanliness and ordered lifestyles. The travellers Adele and Xavier De Hell, for example, observed that 'they admirably availed themselves of the examples set by the 
Germans [Mennonites], and soon attained a high degree of prosperity', commended their 'activity, probity, intelligence, desire of improvement', and concluded by pondering 'how great a change in religion may have on the character and intellect of the Russians' ${ }^{26}$ These witnesses saw the Doukhobors not as a source of direct resistance, but rather as a symbol of the deeper socio-economic progress that began with a rejection of the rituals and hierarchy of Orthodoxy. Approval for the peasant sect was premised on the idea that Russia as a whole was backward and corrupt.

While these voices saw the value of the Doukhobors as being specific to the context of Russia's relative under-development, some on the left saw them representing more widely applicable lessons. In 1898, Kropotkin, then exiled in London, wrote an article on Canada which consisted of a detailed geographical analysis of the country's resources, and in which he contemplated the example of the Mennonites who had migrated from Russian twenty years earlier:

It is a remarkable fact that amidst that capitalist civilisation some twenty thousand men [sic] should continue to live, and to thrive, under a system of partial communism and passive resistance to the State which they have maintained for more than three hundred years. ${ }^{27}$

While written about the Mennonites, Kropotkin's words nevertheless point to several themes that would continue to attract anarchists and other radicals to the Doukhobors. For the scientifically-minded Kropotkin, one key feature was what he saw as the rational basis underpinning this partial communism in that it maximised productivity, rather than this communism simply being a legacy of Mennonites' 'traditional beliefs' and superstition. ${ }^{28}$ 
His article also had real-world significance in that it, and the Mennonites' good reputation, encouraged the Canadian authorities to allow the Doukhobor migration on the grounds that both were hard-working and skilled farming communities who would help transform the prairies.

Positive views of Doukhobor communalism were elaborated and popularised by two individuals above all. From the 1890s, the Social Democrat Vladimir Bonch-Bruevich developed an interest in the Doukhobors, which he carried into high office after the Revolution. ${ }^{29}$ His ethnography of the sect has been influential for later scholars, including Woodcock, and his influence in the Bolshevik Party demonstrates the continued importance of Russian sectarians to communist thought. ${ }^{30}$ In a convergence of political belief and personal interest, Bonch-Bruevich would accompany the Doukhobors on the long sea journey to Canada, where, according to one scholar, he 'found his ideal in the émigré Dukhobory villages', with his book about them 'an ode to sectarian socialism [and] perhaps the most mesmerizing portrait of the narod ever written in Russian. ${ }^{31}$ From a different perspective came Tolstoy, whose anti-hierarchical Christianity has often been seen as essentially anarchist. ${ }^{32}$ In the words of one contemporary, Tolstoy thought that the Doukhobors 'professed the very principles of Christian anarchy' he expressed, and managed to 'put these into actual practice without that disintegrating result so painfully evident in the failure of the Tolstoyan colonies'. ${ }^{33}$ Tolstoy and his followers, along with English Quakers, would provide much of the money and organisation for the sect's emigration to Canada in the 1890s. ${ }^{34}$

Common among the nineteenth-century friends of the Doukhobors - be they pacifist, anarchist, Christian or communist - was the knowledge that the sect was subject to oppression. 
For many of these onlookers the Doukhobors move to Canada was a welcome opportunity for the group to thrive, away from the dictates of a bankrupt autocracy. Yet when they arrived in Canada, far from being able to realise their utopia, they found themselves subject to a new set of pressures. In democratic Canada, both officials and former supporters began to express distaste for the 'doctrines' of the Doukhobors, which were seen as a distraction from their fundamental value as hardworking farmers and potential Canadians (New York Times, November 3, 1929). ${ }^{35}$ Indeed, Kropotkin's friend the political economist James Mavor, who had helped to resettle the Doukhobors, came to argue, contra Kropotkin, that communalism was not necessarily the most rational form of organisation in the context of Canada's modern economy. 'Although they regarded communism as a peculiarly Christian form of social life', he argued, of one faction's decision to continue communal ownership in Canada, 'I am convinced that what really determined their adoption of it were practical considerations', namely the fact that distributing their relatively few possessions to individuals 'was certain to provoke disputes in which they would waste their time and energies' at a time when the colony was far from established ${ }^{36}$ Beyond a settling-in period, Mavor was sceptical about the benefits of living apart from the Canadian economy and society. Indeed, he even proposed that the desire to live in 'simplicity' - a characteristic of the Doukhobors' lives so many found beguiling - essentially amounted to the 'art of ignoring complexity', with a group like the Doukhobors therefore merely transferring 'to others the burdens of its problems' ${ }^{37}$ In the coming decades, thoughts like this would grow, for some Canadians, into feelings of resentment.

The Doukhobors became the subject of such heated debate in the nineteenth century precisely because the group was a vessel for a number of competing political enthusiasms. Their 
obstinate refusal to acquiesce to the demands of the Russian state won them the admiration of both liberal and socialist critics of autocracy, while their religious fervour and practical communism appealed to a range of radicals. The move to Canada fundamentally altered the basis on which support for the Doukhobors rested. Free from tsarist oppression, the Doukhobors' unusual customs now came under greater scrutiny on their own terms, and those seeing the group as model anarchists or communists, would have to make their case anew in the context of a country confident of its democratic credentials.

\section{Ideological Attraction: Anarchizing the Doukhobors}

When Woodcock turned his attention to the group in the 1940s, he was therefore following a familiar path in being attracted to the Doukhobors because of their apparently heroic history of resistance. As he began his intellectual journey in London in the 1930s, the example of the Doukhobors became an important positive model in his political thought. In the time before he left for Canada in 1949, he frequently pondered the example the group afforded radicals intent on building a new world, as economic crisis and world war suggested capitalism's days were numbered. First inspired by his father's stories of the group from his time in Canada, he soon realised that the Doukhobors were more than 'nudist shovellers of snow' or sybaritic nonconformists united in 'complex and orgiastic patterns of shacking-up' ${ }^{38}$ Instead, he started to see the group representing an anarchist community in action.

Woodcock's attraction to anarchism began in the mid-1930s, principally a product of the renewed international attention given to anarchist politics as the Spanish Civil War rumbled on, but also significantly shaped by his developing cultural interests. In a letter to a childhood 
friend written in the midst of the Spanish drama, he demonstrated a precocious sense that the banality of Soviet culture betrayed the kind of society created by the Russian Revolution. 'Although I am a Communist in all the essentials', he wrote, 'there are certain things in official Communism that jar on me':

Particularly the idea...that art must necessarily be turned to political ends. We have seen in Russia the effects of the creed of "art for politics' sake". If anything, it is a more deadly attitude than "art for art's sake". 39

At this time, however, he also demonstrated 'no great [hope]' in Spain's anarchists, praising 'their attitude to the artist', but also seeing them as the 'blind' wreckers of the First International. ${ }^{40}$ This was a cautious endorsement, but as the promise of the Spanish Civil War faded into memory, both the nature of anarchists' contribution, and the perceived role of Stalinism in strangling the revolution, sharpened Woodcock's sense of anarchism's worth.

Woodcock's letter also showed that he was unafraid to challenge anarchist orthodoxies. This is most noticeable in fact that Woodcock identified pacifism as the key force propelling him towards anarchism. Shaped by the disillusioned literary chroniclers of the First World War, he argued that his anarchism emerged from his repudiation of war, since 'one was necessarily putting one's own conscience above the law, and therefore denying the presumptions of the state and legality'. ${ }^{41}$ In the Peace Pledge Union's (PPU) journal, he argued that anarchism is the 'logical end of pacifist thought', and in refusing to fight, whatever the 'political creed' of the refuser, 'he acts as an anarchist, denying the law's...dominion over his acts' ${ }^{42}$ As another war loomed, and with Woodcock this time old enough to fight, he declared himself a conscientious objector, ultimately seeing out the period engaged in agricultural work, initially 
through the communal initiative of The Oaks in Langham, Essex. Founded under the auspices of the PPU by Max Plowman and John Middleton Murry, Woodcock quickly tired of this experiment in communalism. Noting that his fellow communalists were 'on the whole, more intelligent than average', he nevertheless grew frustrated that the lack of privacy hampered his literary ambitions. 'I feel fitter than ever before', he confided, 'but...the fact of writing being impossible has forced me to realise more vividly than before how much it is my raison d'etre.' 43

Kropotkin was the key intellectual influence on his anarchism. As this political identity strengthened in tandem with his growing literary ambitions, Woodcock followed the example Kropotkin set in his classic work Mutual Aid (1902) in looking for anthropological illustrations to buttress his claim that an anarchist society was a viable proposition. He alighted upon the Doukhobors, and in his 1947 pamphlet The Basis of Communal Living, he noted that despite the best efforts of both the Russian and Canadian authorities, the Doukhobors had successfully waged a peaceful war against the state. 'Their "prophet", Peter Verigen [sic], was assassinated by a bomb', he wrote, 'and during both of the last two wars, they have been persecuted for their refusal to accept military service, their young men being imprisoned and all kinds of economic pressure being used to weaken their resistance. ${ }^{44}$ In spite of these efforts, however, he argued that the Doukhobors in their 'communities of Krestova and Brilliant...live in peace and brotherhood, without rules or rulers, without printed regulations or time clocks, regulating their lives on the sense of responsibility within each of them'. Looking at the example of the Doukhobors from a London recovering from war, Woodcock concluded that the group represented the 'best example of a successful 
libertarian community that exists in the world today', an existence won by 'forcing the Canadian authorities' to acknowledge their independence. ${ }^{45}$

Woodcock's comments on the Doukhobors highlight the outlines of his personal anarchist politics, reflecting his anti-state stance, pacifist conception of revolutionary change, and desire for a society in which communal bonds replaced the atomisation of capitalism. ${ }^{46}$ In the first of these, the rejection of the state, he was unexceptional. Writing in 1941 in the influential periodical $N O W$ that he established the previous year, Woodcock struck a characteristically anarchist pose in spying no essential difference between the world's various state structures. He nevertheless sought to update this nineteenth-century argument by wrapping his analysis in the language of totalitarianism. On both 'left and right', every party is moving towards totalitarian control, he argued, and:

The most sinister tendency...is among those elements of the labour party whom the Comintern propagandists... once called 'social fascists.' These men, who have destroyed our liberties more meanly than Hitler could ever have done, prepare the super state that will follow the peace...in which the monstrous army, the still maintained A.R.P. organisations and Trades Unions...proud of their recognition...will provide the basis of the mass movement necessary for our polite but ruthless English fascism. ${ }^{47}$

An older Woodcock would no doubt baulk at the crudity of this forecast, but it expressed the essential logic of a position that saw little difference between the world's various political forms. 'To the individual whose life is frustrated by the law of the state', he commented later, 'it does not matter whether that law is the will of one man or the will of a million', what matters is that 'through its existence he is not free and...cannot be complete'. The very 
definition of liberty purveyed by the liberal democracies was therefore the problem, overlooking as it did the oppressions of majoritarianism and economic inequality. 'Anarchists do not advocate political freedom', he concluded, 'what they... advocate is freedom from politics. $^{48}$

As his comment on the Doukhobors implied, Woodcock believed that they had liberated themselves from politics, but a further point of attraction was the manner of this extraction. The pacifism that had attracted various religiously minded nineteenth-century reformers appealed equally to Woodcock as he attempted to develop his renunciation of political violence into a coherent theory of social change. The key task, he wrote in his polemic Anarchy or Chaos (1944), was to develop a policy of direct action pitched at capitalist economic relations, 'the Achilles heel of the state. ${ }^{49}$ Looking to syndicalism, a political movement that rose to prominence in the years of industrial militancy just before the First World War, he seized on its shibboleth of the general strike as the chief tool of struggle, while highlighting the utility of other syndicalist tactics: 'ca'canny' or 'working slow', the boycott, and sabotage. ${ }^{50}$

Anarchy or Chaos abjured discussing the role of violence in this process, but in contemporary articles Woodcock made it clear that the value of these techniques lay in their potential of avoiding corrupting bloodshed. Contributing an article entitled "The Folly of "Revolutionary" Violence' to the literary journal The Adelphi in 1947, he confessed to being inspired by an earlier essay published in the same organ by Herbert Read. ${ }^{51}$ Read's 1945 work ruminated on the future of Europe in the wake of Germany's surrender, foreseeing a looming crisis in the Soviet Union's 'geodetic vision', a sense that its security depended upon expanding its 
boundaries towards defensible coastlines. The prospect of 'atomization' made this instability all the more dangerous, and he foresaw a bleak role for Britain in the next war, 'dispersed as volcanic dust' under a 'rain of atomic bombs'. Against this fate, Read called for a policy of 'negative or passive resistance', opposing the inevitable militarist response of the British state, while purging our 'aggressiveness' to unleash the potential to build a new world on the basis of 'love and serenity'. 52

Read's demand for a creative politics of compassion in a time of superpower tensions was supremely quixotic, but Woodcock believed that it hinted at a deeper truth concerning the self-defeating nature of political violence. Countering Georges Sorel's argument that revolutionary violence was morally regenerating, Woodcock retorted that, in fact, it encouraged the 'degeneration of moral values'. Aside from the practical chances of revolutionaries winning a fight against professional armies, he added that revolutionary war inevitably undermined the freedom it pursued. 'Any true revolution demands an increasing realization of liberty, equality, and fraternity', Woodcock declared, and 'the needs of war demand the destruction of these qualities'. Against guerrilla fighters and rebel armies, he therefore looked to non-violent struggle as an antidote to the 'self-destructive' effects of revolutionary violence, and, as if challenging an unpersuaded interlocutor, pointed to an example: 'The Doukhobors in Canada give hope that a self-disciplined movement of nonviolent action may bring great achievements in the removal of injustice and establishment of a classless social order of real liberty, equality, and fraternity., ${ }^{53}$

While Woodcock's idealism would fade, the logic of this lesson in the perils of political violence remained a mainstay of his thought. Exploring the tradition of civil disobedience in 
a series of radio talks for the Canadian Broadcasting Corporation (CBC) in 1966, for instance, he praised the 'firm and unresisting' confidence of the Doukhobors in the face of Cossack whippings, noting that the attention their defiance drew paved the way for their escape ${ }^{54}$ But beyond their history of valiant resistance, Woodcock's early appreciation of the Doukhobors rested on a belief that they enshrined a positive kind of freedom; 'a real social vision'. In The Basis of Communal Living, he suggested that this life of liberty pursued in communities in British Columbia had four main attributes: fraternity; the absence of rules; no 'time clocks'; and, in the absence of formal laws, a sense of personal 'responsibility'. 55

Once again the values that Woodcock saw the Doukhobors approximating were a neat encapsulation of his own politics. Despite a defined individualistic streak in his thought, Woodcock was wedded to a concept of community as the locus of meaningful individuality. While he traced the birth of society to recognition that it was 'convenient', therefore, he rejected the idea of 'absolute individual freedom' as impossible, noting that 'one cannot conceive of a society in which man [sic] would be devoid of obligations, ${ }^{56}$ What was needed was a decentralised patchwork of communities in which 'communal relationships of function and neighbourhood' existed, but that also 'bounded [individuals] loosely', guaranteeing space for eccentricity. ${ }^{57}$ In this, Woodcock was following closely the arguments of Kropotkin, who had criticised nineteenth-century utopians for building 'Communist-beehives' that dissolved individual uniqueness in the collective.$^{58}$ Emphasising the importance of 'social organization' allowed Woodcock to disregard the 'serious misconception' that anarchism equalled individualism carried to its 'extreme conclusion'.59 
In their communalism, the early Woodcock saw the Doukhobors achieving this life without written law, but an even more attractive element was their metaphorical destruction of the clock. In 'The Tyranny of the Clock', a 1944 article for Dwight Macdonald's journal politics, Woodcock examined the baneful effects of 'time-conscious[ness]', highlighting the importance of formalised time to the birth of modern capitalism, where the 'regularization and regimentation of life' supported industrial exploitation. ${ }^{60}$ Here Woodcock was mining a rich vein in the history of socialist thought, with Marx, for example, noting that one of Robinson Crusoe's first actions was to fish his watch from the wreckage of his ship. 'Like a true-born Briton', Crusoe begins to 'keep a set of books' detailing necessary labour, and his precious resources. ${ }^{61}$ For all that Crusoe offered Marx a model of liberated labour from which to attack the assumptions of political economy, his comments on Crusoe's diligence pointed as much to his understanding of the nature of British capitalism, where 'time is everything, man is nothing; he is at most, time's carcase'. ${ }^{62}$

Woodcock paralleled Marx's argument that the control of time was central to the functioning of capitalism. Contrasting pre-industrial communities whose conception of time 'is represented by the cyclic processes of nature, the alternation of day and night, the passage from season to season', with 'modern...man' tied to the 'mechanical and mathematical symbols of clock time', his preference was clearly the former. Indeed, while he saw mechanical time as antecedent to capitalism, he saw in the anarchic living conditions of the period - 'the chaotic irregularity which characterized the gin-sodden slums of...nineteenthcentury industrials' - a spontaneous rebellion against the robotic life of the 'factory slave'. ${ }^{63}$ Gin was no lasting solution, however, and liberty did not just mean freedom 'from the rule of men' but also 'from the tyranny of abstractions' ${ }^{64}$ In returning to the rhythms of nature and 
the dignity of the black soil, Woodcock believed that the Doukhobors had achieved this freedom.

In his early appreciation of the Doukhobors Woodcock saw the group as a living embodiment of the political theory he was labouring to develop. Anarchism became a frame for his understanding of the community, and in turn, he used their history as a means of legitimising his own particular political vision. The Doukhobors offered Woodcock a positive model of anarchism in action, and in this, he was in many respects buying into a vision of the group that would have been familiar to a Victorian like Kropotkin. So, as Woodcock packed his trunk in 1949 for a new life on the bosky shores of Vancouver Island, he was excited by the prospect of making contact with a community that had beguiled him from afar for so long. This contact, however, would lead to a dispiriting reassessment.

\section{The Lessons of Experience: Encountering the Doukhobors}

When Woodcock landed in Canada he was excited to hear that a small group of Doukhobors - an 'heretical offshoot' that had separated from the broader community in mainland BC had also made Vancouver Island its home. Given his impression of the group as a 'libertarian sect which took its Christianity neat and turned its settlements into utopian communes', he noted that 'to meet the Doukhobors had been one of my aims' ${ }^{65}$ Yet, contact with the Doukhobors also held the promise of something more practical. As Woodcock and his wife laboured in pursuit of self-sufficiency - striving to turn their unforgiving plot of land into a productive concern - it soon became clear that this was not the Thoureauvian idyll they had 
anticipated from Blitz-damaged London. Coupled with the absence of a defined literary scene in Canada, 'where few authors could then exist by their work alone', Woodcock faced straitened circumstances. ${ }^{66}$ With these concerns in mind the Doukhobors presented themselves as a subject for potentially lucrative journalistic work, as a letter from his friend Dwight Macdonald, then a staff writer at the New Yorker, made clear:

The NYorker MIGHT take a reportage piece on the Doukhobors if it were fast, curious funny enough; lots of odd facts, good stories; could be sympathetic (the editors are all for the underdog and the odd duck) but would have to be phenomenological rather than ideological. ${ }^{67}$

The New Yorker piece never materialised, but it is clear that fascination was not the only reason guiding Woodcock's keenness to meet members of the community.

That first summer Woodcock took a break from his homesteading to hitchhike north to visit the Doukhobor settlement in Hilliers. The community was under the spiritual leadership of Michael 'the Archangel' Verigin, a distant relative of Peter Vasilevich Verigin, who believed that the spiritual and economic purity of the broader community had been tainted by 'evil Canadian influences'. The Hilliers community was an attempt to get back to what they saw as the original Doukhobor principles of a communist economy and communal work, features that Woodcock had praised from afar. While impressed by the fervour of the community the prodigious communal effort that reaped a bounty from their well-tilled land, and their professed commitment to an expansive liberty in which 'no person must have rights over another, either parental or marital' - Woodcock was nevertheless left uneasy. ${ }^{68}$ The pile of empty beer bottles squirrelled away in a distant field suggested that not everyone in the group 
abided by the Doukhobors' teetotalism, and while Woodcock saw this as a 'sign of strain', he spied graver problems. His encounter with 'the Archangel' was dispiriting, and rather than confirming Tolstoy's vision of the Doukhobors as essentially anarchist, he was perturbed by Verigin's seemingly unquestioned power. Similarly, Woodcock found the passive acceptance of the spiritual leader's gnomic utterances - the 'laconic banalities of the oracle' - deeply problematic. ${ }^{69}$ 'From the moment of meeting Michael', he concluded, 'I abandoned my earlier illusions that these were natural anarchists. I recognized theocracy when I saw it. ${ }^{, 70}$

Although Woodcock's direct engagement with the Doukhobors was a source of disappointment, this did not mark the end of his interest in the community. Indeed, it encouraged him to rethink the broader lessons that the Doukhobors' experience offered, a revision that ultimately reflected both his changing conception of anarchist politics, and his shift from being a British writer to becoming a Canadian intellectual with a particular interest in Canadian affairs. Central to the conception of anarchism that he would develop in these years, and his subsequent interventions in Canadian cultural politics, was a sense of Canada's defined regionalism and its engrained federalist tradition. Increasingly concerned by what he saw as a tendency to political centralisation that cut across these Canadian qualities, these fears informed a new perception of the Doukhobors. Rather than exemplars of anarchism, he came to argue that the group's treatment in Canada bore witness to the inability of the modern state to cope with groups whose eccentricities defied the logic of central control and uniformity inherent in the state model. Anarchism remained a central conceptual guide in reaching this Tocquevillian conclusion, ${ }^{71}$ but it was a politics in a different form. 
The frictions between the Canadian state and the Doukhobors that were so important to Woodcock's intellectual development began long before he arrived in the country. While the Doukhobors, like the Mennonites, were exempted from military service, their desire to live communally and generally to not submit to the Canadian state, remained a source of tension. Initially they were allowed to register their land and live together in villages, rather than the single-family homesteads originally envisaged in the Dominion Lands Act of 1872. In 1906, however, the government insisted on the individual registration of land, and required Doukhobor settlers to swear an oath of allegiance. The sect subsequently lost about a third of their holdings, and split into factions: the 'Independents' who were prepared to register their land individually; and the Community Doukhobors, who stayed loyal to the charismatic Peter Vasilevich Verigin, and formed the Christian Community of Universal Brotherhood; and a group later to be called the Sons of Freedom, some of whom would go on to commit bombings and nude marches in protest at materialism and the state custody of Doukhobor children in the 1950s. Under Verigin's leadership, around 8,000 Doukhobors migrated from the prairies to the warmer climate of $\mathrm{BC}$. While their farms and cottage industries again proved successful, the state's preference for private property led to further stresses. With their communally owned property not covered by the Farmers' Creditors Arrangement, which aimed to prevent foreclosures during the depression, the group saw assets worth $\$ 7.5 \mathrm{~m}$ foreclosed for the sake of $\$ 350,000$ debt. In addition, as Canada joined the Allies in 1939, the government showed reluctance to honour section 21 of the Dominion Military Act exempting the Doukhobors from service. Doukhobors in Saskatchewan and Alberta had to undertake alternative service or serve time in prison, while those in BC saw $\$ 5$ per month deducted from their income and sent to the International Red Cross. ${ }^{72}$ 
Efforts to 'integrate' the Doukhobors also stoked tensions. ${ }^{73}$ In the most coercive episode, W.A.C Bennett, Premier of BC between 1952 and 1972, sought to intern forcibly Doukhobor children in schools, in response to the Sons of Freedom's refusal of public education. In 1955 the 'Freedomites' responded by protesting to the UN under the genocide convention, which forbade the separation of a minority's children from their parents. In resisting both this direct coercion and broader attempts at assimilation, the Freedomites were responsible for a decades- long campaign that included nude protests, starting with their first naked pilgrimage in 1902, to bombings in the 1920s and 1960s, usually aimed at public buildings. They also targeted the property of 'Orthodox Doukhobors' whom they accused of betraying their beliefs by cooperating with the state. As the New York Times frantically noted in 1962, the splinter group turned 'British Columbia into... a state close to civil war' (New York Times, March 11 1962). Exasperated by the intransigence of the Sons of Freedom, in the late 1950s, the government even examined the possibility of paying these Doukhobors to emigrate and renounce their Canadian citizenship (New York Times, August 16, 1958).

The 1950s was therefore a climacteric for the Doukhobors in Canada, and for Woodcock too the decade was crucial in shaping his politics, as well as being a period of general intellectual stress. Struggling to establish himself as a writer, he was also reassessing the anarchist commitments that had been central to his self-identity in Britain. In one sense, this was a product of the waning gravitational pull of London's anarchist milieu, but it also reflected broader intellectual changes in the movement that gathered momentum in this decade. ${ }^{74}$ For Woodcock, this amounted to an acceptance that while an anarchist society was ultimately an unlikely proposition, this did not vitiate the utility of anarchism as a 'touchstone by which existing societies could be judged', or the idea of 'partial anarchy in the present', seen in 
multifarious institutions practising mutual aid. ${ }^{75}$ While he noted that it was preparing his highly influential Anarchism: A History of Libertarian Ideas and Movements (1962) that inspired this epiphany, the fruits of this intellectual change had taken time to germinate. Indeed, the first edition of his influential history offered a far more muted take on anarchism's possibilities than his autobiographical comments imply. ${ }^{76}$

With his new approach to anarchism in mind, Woodcock turned to Canadian history, and returned to the Doukhobors. The major product of this historical turn was The Doukhobors, co-written with the Yugoslav-Canadian academic Ivan Avakumović, and published by Oxford University Press. ${ }^{77}$ The book's origins lie in Woodcock's critical review of Simma Holt's 1964 work Terror in the Name of God: The Story of the Sons of Freedom Doukhobors in the Canadian literary magazine Tamarack Review. ${ }^{78}$ Noting the difficulties that confronted the prospective historian of the Doukhobors - their excursive mysticism, hostility to written records, and general distrust of outsiders - Woodcock pointedly observed that 'newsmen run where scholars fear to tread'. He thus objected that Holt unduly focused on a 'minority within a minority within a minority', and seemed more intent on 'passionate exposé' than 'objective history'. The book's 'sensational chapter headings, grotesque nude photographs, and...breathlessly urgent manner' all informed a moralistic argument that skipped 'lightly over the blunders of bureaucrats', and resulted in a call for new laws to deal with the Sons of Freedom menace. This Woodcock rejected:

Special laws against minorities...carry dangers both to the people against whom they are enacted and to the community as whole, since such laws often form the basis for wider attacks on civil liberties. A democracy which accepts the argument that coercion is the only solution to its problems is giving notice of its own abdication. ${ }^{79}$ 
He concluded that for those seeking to break down the barriers of mistrust, Holt's book could only complicate matters, while privately he deemed the work an expression of 'antiDoukhobor prejudice', and lamented that Holt was 'now a Canadian M.P. ${ }^{80}$

Woodcock's The Doukhobors was a direct response to his observation that no valuable scholarly work on the community existed, but two key intellectual traditions also informed the text. On one level, Woodcock was following the model of historical anthropology that anarchists in the nineteenth century, epitomised by Kropotkin, had found especially appealing. In studying human diversity, with particular reference to social customs and decision-making structures, the propagandist was able to highlight the potential to live differently, while equipping his or her arguments with the carapace of disciplinary respectability and objectivity. This was an idea echoed in Woodcock's approach to the First Nations of the Pacific Northwest, as he suggested when responding to a letter from the anarchist Alex Comfort, who had praised The Doukhobors, and hoped to commission a similar work for the Natural History of Society series he was editing for the publisher Nelson. 'The Doukhobor book', Woodcock replied,

sprang from twenty years of interest and connection....but I have been concerned for as long a time with the Indians [sic] of the Pacific Northwest - the polebuilders and potlatch-givers - and would like...to do something on their culture and the effects of contact with white men, which were at first immensely stimulating... but eventually destructive. ${ }^{81}$ 
This politicised historical anthropology underpinned Woodcock's efforts, but another important influence was the emergence of social history as a historical subdiscipline.

Woodcock did not engage in a sustained manner with the historiographical debates informing the rise of social history, and was indeed rather proud of his insulation from the academy as a writer of 'serious non-academic history'. ${ }^{82}$ Nevertheless, in important ways Woodcock's historical imagination was shaped by what a contemporary observer described as the 'liberating effect of the world-wide shift of historical concerns, away from political...into economic, social, and intellectual history' ${ }^{83}$ For Woodcock interestingly, these disciplinary shifts generally informed a renewed contact with the past, rather than an effort to explicitly root his work in contemporary methodological innovations. ${ }^{84}$ Even a late text, like $A$ Social History of Canada (1988), for example, positioned itself in terms of work primarily completed in the 1930s: that of the economic historian Harold Adams Innis and his disciple Donald Creighton. ${ }^{85}$ That both were pioneering historians of Canada obviously lay behind this debt, but equally significant was Woodcock's by this time firmer sense of himself as a Canadian intellectual, engaging with Canadian intellectual problems. Thus, while he was critical of what he saw as Creighton's misreading of the 'Fathers of Confederation' as masquerading centralists, and found Innis' liberal commitment to protecting provincial independence in the face of concentrating power in Ottawa more appealing, he shared with both a sense that Canada was pursuing an independent historical journey, and demanded its own historiography. ${ }^{86}$ With one commentator seeing in Innis' work a 'direct parallel to the insistence of the painters of the Group of Seven for a more authentic, indigenous art freed from the bondage of European paradigms', it is apparent that a parallel concern began to move to the centre of Woodcock's intellectual identity in the $1960 \mathrm{~s} .{ }^{87}$ The distinctiveness of 
the path Canada might pursue was an idea he would imminently turn to, but it also informed an approach to history that was inherently political. Declaring his commitment to popular history, Woodcock thus noted that the power of the work of Creighton and the FrenchCanadian historian Lionel Groulx, lay in its creation of 'actuality' out of sometimes questionable 'factuality', leavening 'laboratory worker' empiricism with 'intemperate' judgements, strong passions, and 'visions powerful enough to sweep us' ${ }^{88}$ Methodologically he may have confessed more affinity with Leo Tolstoy, but this approach to history, informed also by his hours spent studying Kropotkin, ran through Woodcock's scholarship. ${ }^{89}$ The Doukhobors fused this politicised historical anthropology and social history, informing a thesis that recovering the history of the Doukhobors was not simply a scholarly exercise, nor 'controversial journalism' in the manner of Simma Holt, but was crucial for understanding the dynamics of Canadian society. ${ }^{90}$

The Doukhobors, and his review of Holt, highlighted the development of Woodcock's views on the Doukhobors and his new sense of the political lessons afforded by their experiences in Canada. It was certainly one of his most successful and widely reviewed works. With publications as diverse as The British Journal of Sociology, American Historical Review, and American Anthropologist deeming it 'excellent', 'a significant contribution to knowledge' and 'the best...historical study of the Doukhobors', it is apparent that, to academic reviewers at least, Woodcock's book achieved the general level of objectivity he believed lamentably absent in Holt's study. ${ }^{91}$ Certainly he demonstrated a willingness to treat the group more critically than in the past, conceding that Holt was correct in observing that the Doukhobors 'lived under a theocratic system' often mendaciously exploited by their leaders, and that it was 'impossible to deny or condone the acts of violence' perpetrated by the Sons of 
Freedom. ${ }^{92}$ This more reflective critical gaze may have altered, but it did not weaken the political lessons that Woodcock thought the Doukhobors' experience presented. Echoing his broader contemporary effort to rethink anarchism as enduringly relevant in confronting the dominating tendencies of the modern nation state, he now approached the Doukhobors' story as epitomising the state's propensity to control, and its inability to tolerate difference. Woodcock drew this line boldly in his preface, observing that in spite of the "widely divergent systems of government' between autocratic Russia in the nineteenth century, and federalist Canada in the twentieth, both entities struggled to find an adequate solution to the Doukhobor problem. Canada's vastness and the 'spacious makeshift life of the pioneers' may have initially offered tolerance for 'large pockets of eccentricity', but the increasing professionalisation of the state led to conflict. ${ }^{93}$ For all the 'romantic appeal that belongs to lost causes and forlorn hopes', Woodcock therefore judged that the real value of the Doukhobors' history lay in the awkward questions it posed a country seeing itself as a modern democracy:

How well has a democracy succeeded when it has failed to reconcile its most extreme dissenters? How far has the majority...the right to impose its principles and its way of life on a small and at first harmless minority?...Is uniformity in education, or the need for vital statistics, or such a formal point as demanding an oath of allegiance...sufficient justification for penal action....? ${ }^{94}$

Where once the Doukhobors were a positive example of anarchism's real potential, Woodcock now looked on the group as a negative example of the enduring weakness of the nation state. This was a lesson to which he would continually return. 
This refined critique of state power was accompanied by a deepened engagement with Canadian history and society, partly reflecting the fact that from 1968 Woodcock's work would mostly appear through Canadian publishing houses. ${ }^{95}$ Canada now profoundly shaped his sense of self, even if it was defined, in George Fetherling's words, by a consistent 'West Coast bias'. ${ }^{96}$ Canada and the Canadians (1970) was the first and strongest expression of this change, and stressed his belief in the value of regionalism. At the outset, Woodcock confessed that although 'I am averse to nationalism in any political shape', a 'local patriotism' would be evident to his readers. ${ }^{97}$ However this patriotism was an essentially radical commitment, he argued, and foreshadowed a coming resistance to the nation state:

I believe intensely that small local loyalties are the necessary complement to global loyalty, and...that in the next stage of world history we shall see the patrias chicas rising into prominence in the twilight of the great states which are already the dying gods of our present era. ${ }^{98}$

These comments foreshadowed Woodcock's optimistic conclusion that Canada's 'muted' national voice nurtured a productive tension that guaranteed its plurality. Just as the 'French Canadian...Mennonite... Doukhobor or...Indian [sic]' was in a state of 'perpetual vigilance', the greater mass of English-speaking North Americans across the border cultivated a similar watchfulness. Not only did this preclude the 'fevers of aggressive patriotism', but militated against the 'uniformity' that he thought the watchword of the modern state. ${ }^{99}$

These anodyne musings drew directly on Woodcock's anarchism in their defence of federalism as an antidote to the apparently discredited politics of the monolithic nation state. Unusually, however, in Canada and the Canadians Woodcock identified an unexpected ally 
in this commitment to radical federalism, in the shape of recently elected Liberal Party Prime Minister Elliott Trudeau. Seeing Trudeau as exemplifying the 'collective genius of Canada' in stressing the 'perils of nationalism and the importance of federalism', he argued that this had ramifications broader than domestic politics and could be 'a principle for the restructuring of global politics'. ${ }^{100}$ Reviewers were quick to diagnose Woodcock's unlikely Trudeaumania and criticise his 'naiveté', and while he would later become a fierce critic of Trudeau, this act of ideological misrecognition highlights the importance he attached to the idea that Canada had the potential to pursue a radically different path; a path that would allow groups like the Doukhobors to maintain their distinctive way of life. ${ }^{101}$ Indeed, the optimism that informed this vision had, Woodcock conceded later, obvious contextual origins in what Trudeau himself described as a 'mood of...festivity' in the wake of the Centennial of Confederation celebrations and Expo'67. ${ }^{102}$ Their real significance, however, lies in Woodcock's understanding of the necessary interrelation of federalism, regional difference, and local patriotism. Real federalism, the achievement of 'local autonomy and direct democracy' that left space for the cultural idiosyncrasies of the patria chicas, was the sort of system that would not stultify the independence of a group like the Doukhobors in forcing their assimilation. This, he held, was a 'truly revolutionary' model, and it was an idea Woodcock would remain committed to after his momentary optimism for the future of conventional politics disappeared. ${ }^{103}$

Initially seeing Trudeau as representing a deeper commitment to a pioneering form of federalism, and briefly enchanted by what one historian sees as the 'fire of passionate promise for the future' at the heart of Trudeau's campaign, Woodcock soon cooled to the politician. ${ }^{104}$ Indeed he later saw Trudeau, in his efforts to patriate Canada's constitution and 
thereby wrest ultimate oversight from Westminster, as a centraliser, using patriation as a ruse to re-concentrate in Ottawa 'power that in recent decades has rightfully flowed to the regions. ${ }^{105}$ This amounted to a reversal of the desires Woodcock voiced in Canada and the Canadians, and as he returned to the fray to champion federalism and local democracy, the Doukhobors soon reappeared in his writing as an exemplar of the inadequacies of the nation state. Reviewing Koozma Tarasoff's pictorial history of the Doukhobors in 1974, he parodied the rhetoric of assimilation to mourn the cost of integration:

The Doukhobors have become good citizens...We have overcome! We have assimilated the Doukhobors, and most of us fail to realize that in forcing a minority culture to abandon almost all that declares its identity...we have admitted that no more than totalitarian states can our kind of democracy find room within it for a radically dissenting group. ${ }^{106}$

Woodcock expanded this theme in the first of a regular column for the Vancouver newspaper The Georgia Straight in 1976. Fresh from making a series of what he described as 'elegiac' films on the Doukhobors for the $\mathrm{CBC}$, he argued in his column that 'their fate is an example of what happens to...[a]...different minority caught in the social meat grinder of a large modern state, whether it is democratic or dictatorial, capitalist or communist. ${ }^{107}$ While individual members of the community had prospered following their capitulation to 'the Canadian pattern of individual free enterprise', Woodcock held up their experience as an indictment of the Canadian state, arguing that 'Canada as a democracy stands condemned'. Unable to make space 'any more than Russian autocrats' for a minority that rejected the status quo, he concluded that this betrayed the weakness of 'our devotion to freedom', and that, 'at best, we enjoy...a little more liberty than the frankly authoritarian countries'. ${ }^{108}$ 
With his hopes that Canada was pursuing a path of radical federalism frustrated, Woodcock feared that the country was instead heading down a familiar path of political centralisation and intolerance in which the example of the Doukhobors was especially salient. Pitching an article to the American libertarian magazine Inquiry, he made his position explicit:

We regionalists argue Trudeau's "federalism" is...merely a disguised centralism and that he is seeking to sustain the nineteenth-century nation-state when Canada could give a lead by creating an example of a genuine working federalism of autonomous regions. ${ }^{109}$

In this spirit, The Canadians (1979) seized the opportunity to lambast governmental folly in the treatment of the Doukhobors, and to undercut what he presented in his letter as historical backsliding. The state's insistence on the oath of allegiance that caused the Doukhobors' migration to $\mathrm{BC}$ was an example 'of the unimaginative attitude of the Canadian government...[and] lead to generations of conflict'. Moreover, he reiterated a favourite theme, insisting that Canada's size meant that the country was 'not a national state in the usually accepted sense' and any 'attempt to tidy it up into a centralized nation-state would bring its immediate disintegration.' ${ }^{110}$ Post-Trudeau, Woodcock was clearly still anxious that the forces of political centralisation he represented remained at work. In The Century That Made Us: Canada 1814-1914 (1989), he repeated his thesis that the Doukhobors' experience was a warning about the inadequacies of majoritarianism:

Once again it was a matter of a democratic society attuned to the idea of the majority...having no room for eccentric social or economic...viewpoints particularly if they led beyond theory into action and resulted in social enclaves that followed different ways of life from the accepted ones. ${ }^{111}$ 
As the seeming threat posed by the Doukhobors to Canadian society was eased by their assimilation, their story would remain, in Woodcock's view, a lesson that a mass, democratic society should not forget. Contributing a piece on the Doukhobors' to James Marsh's The Canadian Encyclopedia, he struck a plangent tone in an entry that reflected the distance that the Doukhobors had travelled in his lifetime, from radical heretics to good Canadian citizens. One of the "largest and most complex undertakings in communal living in N. American history' was over, he concluded, and now only pockets of 'various Doukhobor groupings...struggle to forestall the effects of encroaching assimilation. ${ }^{112}$

\section{Conclusion}

Today, visitors to the Doukhobor Discovery Centre without the necessary cash to meet the $\$ 10$ entrance fee will be sent back over the highway to the only ATM in the area, housed in a gaudy casino, the noise of the traffic punctuated by the din of serried slot machines. Sitting on a hill overlooking the Columbia River, and laying close to the unassuming town of Castlegar, the juxtaposition of the Discovery Centre and the casino illustrates the changes that have shaped Canadian society since Woodcock first looked to the Doukhobors for inspiration; changes that, ultimately, this group of radical Christians were unable to resist. It is not difficult to imagine Woodcock noticing these encroachments of modern life, and lamenting the decline of the Doukhobor movement as he saw its distinctiveness washed away in the broader tidal currents of Canadian culture. The Centre, a simulacrum of a Doukhobor homestead in the early twentieth century replete with the everyday artefacts that memorialise their defining slogan 'Toil and Peace Life', is a protest against this process. Moreover, in its 
focus on the journey that the Doukhobors took from Russia to Canada, and on the troubled years when they attempted to establish a foothold in Saskatchewan and then BC, it stands as a reminder that there was far more to the Doukhobor experience than nude marches across the prairies or the conflagrations of the Sons of Freedom. Woodcock would have appreciated these efforts, and recognised the importance of remembering the experiences of a group to which he devoted so much intellectual energy, but he would no doubt also have seen the Discovery Centre as a clear reminder of the price exacted by the forces of assimilation.

For all the change that characterised his life - the geographical relocation, the prodigious and varied publishing record - his interest in the Doukhobors was a constant. He remained fascinated by their history, and continued to be a passionate advocate for their rights; rights he believed imperilled by changes underway in Canadian politics and society. Yet his interpretation of the group itself shifted, and this process of rethinking reflects both his mutating political attachments, and his changing self-identity. While once the Doukhobors were the embodiment of a radical politics that gave Woodcock his initial intellectual energy, the discomfitures of experience stripped away his enthusiasm.

Yet, as his politics altered from a militant anarchism to a 'pragmatic' libertarianism, and he was reborn as a Canadian rather than a British writer, the Doukhobors' history remained important to him. There were important continuities in these intellectual shifts. As one commentator recognised, running through Woodcock's 'extensive oeuvre...[is]... a central concern with freedom, individuality and...eccentricity and waywardness' that made the Doukhobors such an appealing group in the first place. ${ }^{113}$ But with these philosophical and practical changes, how he understood the Doukhobors changed. Their theocracy belied the 
idea that these were anarchists, but as he began to see anarchism as a theoretical compass particularly adept at identifying and exposing authoritarianism, the Doukhobors' history offered something different. While others have appreciated the depth of his interest in the Doukhobors, their utility as an intellectual weather-vane, pointing to the shifts in his cultural politics, has been missed. ${ }^{114}$ Here was a group that, rather than showing anarchy in action, demonstrated that even ostensibly democratic states struggled with difference, and even democratic cultures tended towards assimilation and conformity. His was 'A Plea for the Anti-Nation', and perhaps in this way, through a radical decentralisation coupling autonomy with empowering responsibility, he hoped the Canadian mosaic would no longer be illusory. ${ }^{115}$

\section{Notes}

${ }^{1}$ Woodcock and Avakumović, Anarchist Prince, 283.

${ }^{2}$ Tippett, Made in British Columbia, 79; Woodcock, Walking Through the Valley, 47

${ }^{3}$ Hughes, Woodcock, 13.

${ }^{4}$ Purdy, 'George Woodcock', 168.

${ }^{5}$ Kropotkin, Memoirs of a Revolutionist, 157.

${ }^{6}$ Woodcock and Avakumović, The Doukhobors, 19.

${ }^{7}$ Androsoff, 'Pacifist "Terrorists", 2; Woodcock, Doukhobors, 19; Androsoff, "Spirit Wrestling”, 198-199.

${ }^{8}$ Antliff and Adams, Anarchist Studies. This journal special issue is a rare exception, but does not deal with the Doukhobors.

${ }^{9}$ For such a static reading, see: Fetherling, The Gentle Anarchist, 126-9. For a thoughtful discussion of his politics, see: Antliff, "Pacifism, Violence and Aesthetics", 15-44.

${ }^{10}$ Gwyn, Northern Magus, 49. 
${ }^{11}$ Chertkov, "Christian Martyrdom in Russia," p. 2; Author unknown [A.U], "The SpiritWrestlers One Hundred Years Ago: a paper written in 1805," 16; Woodcock andAvakumović, The Doukhobors, 19.

${ }^{12}$ Ebenezer Henderson, "Travels to the Dukhobortsy Living on the Molochnaya River, 1818".

${ }^{13}$ Chertkov, Christian Martyrdom in Russia 3; A.U.., "The Spirit-Wrestlers One Hundred Years Ago," 22.

${ }^{14}$ Stepniak, "Rationalistic Dissent"; Albert F. Heard, The Russian church and Russian dissent, comprising orthodoxy, dissent, and erratic sects, 252.

15 Henderson, "Travels to the Dukhoborsty."

${ }^{16}$ Pinkerton, "A Visit to the Dukhobortsy on the Sea of Azov, 1816."

${ }^{17}$ Josh Sanborn, "Pacifist politics and peasant politics: Tolstoy and the Doukhobors," 52-72;

Tolstoy, Donskov, and Woodsworth, Leo Tolstoy and Russian Peasant Sectarian Writers:

Selected Correspondence.

${ }^{18}$ First recorded in the eighteenth century, the origins of the Doukhobors remain disputed. Some see them as deriving from the Raskolniks or Old Believers, Russians rejecting changes to the Orthodox liturgy in the seventeenth century. Others argue that they were influenced by Bulgarian Bogomils in the thirteenth and fourteenth centuries, by English Quakers, or by a wandering hermit deserted from the Russian army, while in Soviet times historians sought to understand the origins of the Doukhobors in materialist terms. Woodcock, Doukhobors, 2527; Klibanov and Dunn, History of Religious Sectarianism.

${ }^{19}$ Woodcock, Doukhobors, 54.

${ }^{20}$ Ibid., 53-61.

${ }^{21}$ Breyfogle, Heretics and Colonizers, 22.

${ }^{22}$ Woodcock, Doukhobors, 84-106.

${ }^{23}$ Alston, "A Great Host of Sympathisers," 200-215; Kelly, 'Christianity and Humanitarianism in the Doukhobor Campaign," 339-355.

${ }^{24}$ Herzen, My Life and Thoughts, 647-648.

${ }^{25}$ Ibid., 272-274.

${ }^{26}$ Adele and Xavier Hommaire de Hell, "Travels Among the Molochnaya Dukhobortsy."

${ }^{27}$ Kropotkin, "Some of the Resources of Canada", 504.

${ }^{28}$ Ibid., 505. See also: Adams, Kropotkin, Read, and the Intellectual History of British Anarchism.

${ }^{29}$ Klibanov, Religious Sectarianism, 5-6, 139; Etkind, "Whirling with the Other," 584-5. 
${ }^{30}$ Engelstein, Castration and the Heavenly Kingdom, 3.

${ }^{31}$ Etkind, "Whirling with the Other", 584.

${ }^{32}$ Consider: Christoyannopoulos, Christian Anarchism.

${ }^{33}$ Maude, Peculiar People, 164.

${ }^{34}$ Alston, Tolstoy and his Disciples.

${ }^{35}$ Elkington, The Doukhobors, 79.

${ }^{36}$ Mavor, My Windows on the Street, 12.

${ }^{37}$ Ibid., 37.

${ }^{38}$ Woodcock, Beyond the Blue Mountains, 6.

${ }^{39}$ George Woodcock to J.L. Goodwin: Undated, George Woodcock Papers, Queen's University, Ontario [Hereafter: GWPQU]: Box 2 File 12.

${ }^{40}$ Woodcock to Goodwin: Undated.

${ }^{41}$ Woodcock, Letter to the Past, 187.

${ }^{42}$ Woodcock, "Anarchy, says George Woodcock," 7.

${ }^{43}$ George Woodcock to J.L. Godwin: 7 February 1941', GWPQU: 2:12.

${ }^{44}$ Woodcock, Basis of Communal Living, 12.

${ }^{45}$ Ibid., 12.

${ }^{46}$ See also: Antliff, 'Pacifism, Violence and Aesthetics'.

${ }^{47}$ Woodcock, "Commentary," 34.

${ }^{48}$ Woodcock, Anarchy or Chaos, 20, 108.

${ }^{49}$ Ibid., 120.

${ }^{50}$ Ibid., 87.

${ }^{51}$ Woodcock, “The Folly of 'Revolutionary' Violence,” 55.

${ }^{52}$ Read, "There Is Now No Other Way," 10, 15, 11.

${ }^{53}$ Woodcock, “"Revolutionary” Violence', 55, 57, 61.

${ }^{54}$ Woodcock, Civil Disobedience, 48.

${ }^{55}$ Woodcock, Communal Living, 12.

${ }^{56}$ Woodcock, Anarchy or Chaos, 14, 105. 
${ }^{57}$ Woodcock, Communal Living, 37.

${ }^{58}$ Kropotkine, "Communism and Anarchy," 31. For more on this, see: Adams, "Rejecting the American Model."

${ }^{59}$ Woodcock, Anarchy or Chaos, 21.

${ }^{60}$ Woodcock, "The Tyranny of the Clock," 266.

${ }^{61}$ Marx, Capital, 88.

${ }^{62}$ Marx, Poverty of Philosophy, 54; Marx, Capital, 220, 184. See also: Kemple, Reading Marx Writing, 137.

${ }^{63}$ Woodcock, "Tyranny of the Clock”, 265, 266.

${ }^{64}$ Ibid., 267.

${ }^{65}$ Woodcock, Blue Mountains, 6.

${ }^{66}$ Ibid., 14.

${ }^{67}$ Dwight Macdonald to George Woodcock: $28^{\text {th }}$ April 1950, GWPQU: 3:17.

${ }^{68}$ Woodcock, "Encounter with an Archangel," 34.

${ }^{69}$ Ibid., 36.

${ }^{70}$ Woodcock, Beyond the Blue, 13.

${ }^{71}$ For Woodcock's view on Tocqueville, consider: Woodcock, Walking through the Valley, 53.

${ }^{72}$ Popoff, "The Doukhobors," 22-48.

73 Jaenen, "The Doukhobor," 103-113.

${ }^{74}$ Pauli, “The New Anarchism," 134-155.

${ }^{75}$ Woodcock, Blue Mountains, 94.

${ }^{76}$ Woodcock, Anarchism, 450, 443.

${ }^{77}$ As with Woodcock's previous collaboration with Avakumović, Woodcock was primarily responsible for writing the text, with Avakumović concentrating on translating Russianlanguage materials, and responding to draft chapters. For more on this process see: Fetherling, Gentle Anarchist, 67-68, 126-129.

${ }^{78}$ Woodcock, Blue Mountains, 131.

${ }^{79}$ Woodcock, "The Sons of Freedom, 96, 97, 98, 99.

${ }^{80}$ George Woodcock to Alan Hodge: $16^{\text {th }}$ December 1976, GWPQU: 1:17. 
${ }^{81}$ George Woodcock to Alex Comfort: $15^{\text {th }}$ April 1969, GWPQU: 2:06

${ }^{82}$ Woodcock, The Century That Made Us. In this, Woodcock in some respects stood closer to nineteenth century Canadian historical writing, which tended to be 'non-professional, a branch of literature; most of it, also, had political purpose'. McNaught, Penguin History of Canada, 382.

${ }^{83}$ Hanham, "Canadian History in the 1970s," 4.

${ }^{84}$ Berger, Writing of Canadian History, 319.

${ }^{85}$ Woodcock, Social History, 3.

${ }^{86}$ Woodcock, "The Servants of Clio,” 140; Berger, Canadian History, 104.

${ }^{87}$ Berger, Canadian History, 91.

${ }^{88}$ Woodcock, 'Servants of Clio', 133, 131, 140.

${ }^{89}$ Woodcock, Social History, 6.

${ }^{90}$ Woodcock, Doukhobors, 374.

${ }^{91}$ Whitworth, "The Doukhobors," 459; Bourdreau, "The Doukhobors," 1754; Frantz, "The Doukhobors," 941. See also: Fetherling, Gentle Anarchist, 149

${ }^{92}$ Woodcock, "Sons of Freedom,” 98.

${ }^{93}$ Woodcock, Doukhobors, 11, 10.

${ }^{94}$ Ibid.,11.

${ }^{95}$ Woodcock, Walking through the Valley, 27.

${ }^{96}$ Fetherling, Gentle Anarchist, 193; Woodcock, Blue Mountains, 18.

${ }^{97}$ Woodcock, Canada and the Canadians, 16, 15.

${ }^{98}$ Ibid., 15.

${ }^{99}$ Ibid., 318.

${ }^{100}$ Woodcock, Canada and the Canadians, 235, 321.

${ }^{101}$ Fox, "Canada Portrayed," 93. For a description of this phenomenon, see: English, Just Watch Me, 13-14.

102 Trudeau, Memoirs, 100; Woodcock, Canada and the Canadians, 18; Woodcock, Blue Mountains, 189.

${ }^{103}$ Woodcock, Walking Through the Valley, 59, 60.

${ }^{104}$ Palmer, Canada's 1960s, 175. 
${ }^{105}$ Woodcock, Confederation Betrayed!, 7.

${ }^{106}$ Woodcock, "The Doukhobors: A Sad Epic," 13.

107 This description of the films came in a letter to History Today editor Alan Hodge. George Woodcock to Alan Hodge: $28^{\text {th }}$ November 1976, GWPQU, 1:17; Woodcock, "Against the Tide," $6,7$.

${ }^{108}$ Woodcock, "Against the Tide," 6, 7.

${ }^{109}$ George Woodcock to Ralph Raico: $2^{\text {nd }}$ March 1978, GWPQU: 4:90.

${ }^{110}$ Woodcock, The Canadians, 175, 300.

${ }^{111}$ Woodcock, Century That Made Us, 190.

112 Woodcock, "The Doukhobors," 616.

${ }^{113}$ Duffy, “George Woodcock," 156.

${ }^{114}$ Fetherling, Gentle Anarchist, 126-9.

115 Woodcock, "A Plea for the Anti-Nation," 16-19.

\section{Bibliography}

Author unknown, "Several characteristics of Doukhobor society, 1805." Translated by Robert Pinkerton, Doukhobor Genealogy Website. Accessed March 10, 2017.

http://www.doukhobor.org/Platon.html

Author unknown, "The Spirit-Wrestlers One Hundred Years Ago: a paper written in 1805," in Chertkov, Vladimir, Christian Martyrdom in Russia: Persecution of the Spirit-wrestlers (or Doukhobortsi) in the Caucasus. Croydon: Brotherhood Publishing Company, 1897, 16-35.

Adams, Matthew S. "Rejecting the American Model: Peter Kropotkin's Radical Communalism." History of Political Thought 35, no.1 (2014): 147-173.

Adams, Matthew S. Kropotkin, Read, and the Intellectual History of British Anarchism: Between Reason and Romanticism. Basingstoke: Palgrave Macmillan, 2015.

Alston, Charlotte. "“A Great Host of Sympathisers': The Doukhobor Emigration and its International Supporters.” Journal of Modern European History 12, no.2 (2014): 200-215.

Alston, Charlotte. Tolstoy and his Disciples: the History of a Radical International Movement. London: I.B. Tauris, 2014.

Androsoff, Ashleigh. "Spirit Wrestling: Identity Conflict and the Canadian 'Doukhobors Problem, 1889-1999”. PhD diss., University of Toronto, 2011. 
Androsoff, Ashleigh. 'Pacifist 'Terrorists' in the 'Peaceable Kingdom': Cultural Conflict in Twentieth-Century Canada." Journal for the Study of Radicalism 7, no.1 (2013): 1-35.

Antliff, Allan \& Matthew S. Adams. Anarchist Studies 23, no.1 (2015)

Antliff, Mark. "Pacifism, Violence and Aesthetics: George Woodcock's Anarchist Sojourn, 1940-1950." Anarchist Studies 23, no.1 (2015): 15-44.

Berger, Carl. The Writing of Canadian History: Aspects of English-Canadian Historical Writing since 1900. London: University of Toronto Press, 1986.

Bourdreau, J.A. “The Doukhobors.” American Historical Review 74, no.5 (1969) 1753-1754.

Breyfogle, Nicholas B. Heretics and Colonizers: Forging Russia's Empire in the South Caucasus. London: Cornell University Press, 2005.

Chertkov, Vladimir, Christian Martyrdom in Russia: Persecution of the Spirit-wrestlers (or Doukhobortsi) in the Caucasus. Croydon: Brotherhood Publishing Company, 1897.

Christoyannopoulos, Alexandre. Christian Anarchism: A Political Commentary on the Gospel. Exeter: Imprint Academic, 2011.

Duffy, Dennis. “George Woodcock: Voyager of Liberty.” Canadian Literature 83 (1979): 156-162.

Elkington, Joseph. The Doukhobors: Their History in Russia: Their Migration to Canada. Philadelphia: Ferris \& Leach, 1903.

Engelstein, Laura. Castration and the Heavenly Kingdom: A Russian Folktale. London: Cornell University Press, 1999.

English, John. Just Watch Me: The Life of Pierre Elliott Trudeau, 1968-2000. Toronto: Knopf, 2009.

Etkind, Aleksandr. "Whirling with the Other: Russian Populism and Religious Sects." The Russian Review 62 (2003): 565-588

Fetherling, George. The Gentle Anarchist: A Life of George Woodcock. Vancouver: Subway, 2003.

Fox, C.J. “Canada Portrayed.” Canadian Literature 49 (1971): 92-94.

Frantz, Ch. “The Doukhobors.” American Anthropologist 71, no.5 (1969): 940-941.

Gwyn, Richard. The Northern Magus: Pierre Trudeau and Canadians. Toronto: McClelland \& Stewart, 1980.

Hanham, H.J. "Canadian History in the 1970s." The Canadian Historical Review 58, no.1 (1977): 2-22 
Heard, Albert F., The Russian church and Russian dissent, comprising orthodoxy, dissent, and erratic sects. New York: New York, Harper \& brothers, 1887.

Henderson, Ebenezer, "Travels to the Dukhobortsy Living on the Molochnaya River, 1818," Doukhobor Genealogy Website. Accessed March 10, 2017.

http://www.doukhobor.org/Platon.html.

Herzen, Alexander. My Life and Thoughts: The Memoirs of Alexander Herzen. Translated by Constance Garnett. London

Hommaire de Hell, Adele and Xavier. "Travels Among the Molochnaya Dukhobortsy, 18391841.” Doukhobor Genealogy Website. Accessed November 29, 2016.

http://www.doukhobor.org/HommaireDeHell.html

Hughes, Peter. George Woodcock. Toronto: McClelland and Stewart, 1974.

Jaenen, Cornelius. "The Doukhobors first perceived as the 'other'." In The Doukhobor

Centenary in Canada: A Multi-Disciplinary Perspective on their Unity and Diversity, edited by Andrew Donskov et al. Ottawa: University of Ottawa Press, 2000: 103-113.

Kelly, Luke. "Christianity and Humanitarianism in the Doukhobor Campaign, 1895-1902." Cultural and Social History 13, no.3 (2016): 339-355.

Kemple, Thomas M. Reading Marx Writing: Melodrama, the Market, and the "Grundrisse". Stanford: Stanford University Press, 1995.

Klibanov, T.I. History of Religious Sectarianism in Russia, 1860-1917. Oxford: Pergamon Press, 1982.

Kropotkin, Peter. "Some of the Resources of Canada." The Nineteenth Century. (1898): 495515.

Kropotkin, Peter. Memoirs of a Revolutionist. London: Folio Society, 1978.

Kropotkine, Peter. "Communism and Anarchy." Freedom: A Journal of Anarchist Communism (1901): 30-31.

Marx, Karl. Capital. Translated Samuel Moore and Edward Aveling. New York: Modern Library, 1906.

Marx, Karl. The Poverty of Philosophy. Moscow: Foreign Languages Publishing House, N.D. Maude, Aylmer. A Peculiar People: the Doukhobors. London: Archibald Constable, 1905.

Mavor, James. My Windows on the Street of the World. London. J.M. Dent, 1923.

McNaught, Kenneth. The Penguin History of Canada. London: Penguin, 1988.

Miller, David. Anarchism. London: J.M. Dent, 1984. 
Palmer, Bryan D. Canada's 1960s: The Ironies of Identity in a Rebellious Era. London: University of Toronto Press, 2009.

Pauli, Benjamin J. "The New Anarchism in Britain and the US: Towards a richer understanding of post-war anarchist thought." Journal of Political Ideologies 20, no.2 (2015): 134-155.

Pinkerton, Robert, "A Visit to the Dukhobortsy on the Sea of Azov, 1816," Doukhobor Genealogy Website. Accessed March 10, 2017. http://www.doukhobor.org/Platon.html.

Popoff, Eli A. "The Doukhobors: the 'enigma' and the reality." In The Doukhobor Centenary in Canada: A Multi-Disciplinary Perspective on their Unity and Diversity, edited by Andrew Donskov et al. Ottawa: University of Ottawa Press. 2000: 22-48.

Purdy, Al. "George Woodcock." In A Political Art: Essays and Images in Honour of George Woodcock, edited by William H. New, 168-169. Vancouver: University of British Columbia Press, 1978.

Read, Herbert. "There is Now No Other Way: An Appeal to Youth.” The Adelphi 22, no.1 (1945): 9-16.

Sanborn, Josh, "Pacifist politics and peasant politics: Tolstoy and the Doukhobors, 18951899," Canadian Ethnic Studies, 27, no. 3, (1995): 52-72.

Stepniak, Sergius, "Rationalistic Dissent." Chap. 7 in The Russian Peasantry, Their Agrarian Condition, Social Life and Religion. London: Sonnenschein, 1894.

Tippett, Maria. Made in British Columbia: Eight Ways of Making Culture. Madeira Park, BC: Harbour, 2015.

Trudeau, Pierre Elliott. Memoirs. Toronto: McClelland \& Stewart, 1993.

Tolstoy, Leo, Donskov, Andrew, and Woodsworth, John, Leo Tolstoy and Russian Peasant Sectarian Writers: Selected Correspondence. Ottawa: Slavic Research Group, University of Ottawa, 2008.

Whitworth, John. “The Doukhobors.” British Journal of Sociology 20, no.4 (1969): 459-460.

Woodcock, George. \& Ivan Avakumović, The Anarchist Prince. London: T.V. Boardman, 1950 .

Woodcock, George. \& Ivan Avakumović, The Doukhobors. Toronto: Oxford University Press, 1968.

Woodcock, George. “Commentary.” NOW: A Journal of Good Writing. (1941): 34-36.

Woodcock, George. Anarchy or Chaos. London: Freedom Press, 1944.

Woodcock, George. “The Tyranny of the Clock.” politics (1944), 265-267. 
Woodcock, George. "“Anarchy, says George Woodcock, is 'the logical end of pacifist thought."” PPU Journal. (1946): 7+9.

Woodcock, George. The Basis of Communal Living. London: Freedom Press, 1947.

Woodcock, George. "The Folly of 'Revolutionary' Violence.” The Adelphi 23, no.2 (1947): 55-61.

Woodcock, George. Anarchism: A History of Libertarian Ideas and Movements. London: Penguin, 1962.

Woodcock, George. “Encounter with an Archangel.” The Tamarack Review (1963): 29-40.

Woodcock, George. “The Sons of Freedom.” The Tamarack Review (1965): 95-100.

Woodcock, George. Civil Disobedience. Toronto: Canadian Broadcasting Corporation, 1969.

Woodcock, George. Canada and the Canadians. London: Faber, 1970.

Woodcock, George. “A Plea for the Anti-Nation.” The Canadian Forum (1972) 16-19.

Woodcock, George. “The Doukhobors: A Sad Epic.” Books in Canada 3, no.3 (1974): 13.

Woodcock, George. “Against the Tide.” Georgia Straight (1976): 6-7.

Woodcock, George. The Canadians. Don Mills, ONT: Fitzhenry \& Whiteside, 1979.

Woodcock, George. "The Servants of Clio: Notes on Creighton \& Groulx." Canadian Literature 83 (1979): 131-141.

Woodcock, George. Confederation Betrayed! The Case Against Trudeau's Canada. Madeira Park, BC: Harbour Publishing, 1981.

Woodcock, George. Letter to the Past: An Autobiography. Toronto: Fitzhenry \& Whiteside, 1982 .

Woodcock, George. Beyond the Blue Mountains: An Autobiography. Toronto: Fitzhenry \& Whiteside, 1987.

Woodcock, George. A Social History of Canada. London: Penguin, 1988.

Woodcock, George. "The Doukhobors." In The Canadian Encyclopedia: A-Edu, edited by James H. Marsh, 616-617. Edmonton: Hurtig Publishers, 1988.

Woodcock, George. The Century That Made Us: Canada 1814-1914. Toronto: Oxford University Press, 1989.

Woodcock, George. Walking Through the Valley: Autobiography. Oakville, ON: ECW Press, 1994. 